\title{
Prediction of preterm delivery with a novel bedside test
}

\author{
Pallavi S. Vishwekar ${ }^{1 *}$, Anahita R. Chauhan ${ }^{1}$, Naju Turakhia ${ }^{2}$
}

\begin{abstract}
${ }^{1}$ Department of Obstetrics and Gynecology, Seth GS Medical College and KEM Hospital, Mumbai, Maharashtra, India
\end{abstract} ${ }^{2}$ Clinical Research, Scientific Research Solutions, Arcadia, Nariman point, Mumbai, Maharashtra, India

Received: 04 July 2017

Accepted: 14 July 2017

\section{*Correspondence:}

Dr. Pallavi S. Vishwekar,

E-mail: drpallavibasapure@gmail.com

Copyright: (c) the author(s), publisher and licensee Medip Academy. This is an open-access article distributed under the terms of the Creative Commons Attribution Non-Commercial License, which permits unrestricted non-commercial use, distribution, and reproduction in any medium, provided the original work is properly cited.

\begin{abstract}
Background: Preterm birth occurs in 7 to $12 \%$ of all deliveries but account for $85 \%$ of perinatal morbidity and mortatity. Hence, there is a need for a reliable test to predict the onset of preterm labour. One such test is detection of phosphorylated insulin like growth factor binding protein 1 (phIGFBP-1) in cervical secretion with a simple bedside kit that is recently commercialized Actim Partus kit.

Methods: This was a prospective study carried out at a tertiary hospital over a period of 2 years from October 2006 to November 2008. Women between 28 to 37 weeks with intact fetal membranes, who presented with threatened preterm labour were included and followed up till delivery. Time interval between test and delivery, weeks of gestation at the time of delivery, labour and delivery details as well as neonatal outcome were documented. Diagnostic accuracy of the test was determined by sensitivity, specificity, positive and negative predictive value.

Results: It was found that this test was extremely sensitive in prediction of preterm delivery and negative test results implied low chance of preterm delivery as in the patients with positive test result the average time of prolongation of pregnancy was less than 24 hours and in patients with negative test result it was more than 7 days which was statistically significant $(\mathrm{P}$ value $=0.001)$. The need for NICU and perinatal morbidity was significantly less in patients with negative test result.

Conclusions: There is a role of detection of cervical IGFBP-1 test in the management of women presenting with suspected preterm labour which allows us to focus on patients who are more likely to deliver preterm and also to reduce perinatal mortality and morbidity.
\end{abstract}

Keywords: Phosphorlylated insulin like growth factor binding protein 1 (ph IGFBP), Preterm delivery, Prediction

\section{INTRODUCTION}

Preterm labour refers to the onset of labour after fetal viability but before 37 completed weeks of gestation. The diagnostic criteria are onset of increasingly frequent and painful uterine contractions (at least 4 contractions per 20 minutes) with progressive effacement and dilatation of cervix i.e. $80 \%$ cervical effacement and at least $2 \mathrm{~cm}$ dilatation (or cervical length $<1 \mathrm{~cm}$ ). Threatened preterm labour may be diagnosed with documented uterine activity but no cervical changes. Preterm births occur in 6-11\% of all deliveries but account for over $85 \%$ of perinatal morbidity and mortality. ${ }^{1}$ The morbidity, mortality and economic burden of these cases are highest at lower gestational ages and even in babies that survive, there is high risk of short and long term morbidity like respiratory distress syndrome, necrotizing enterocolitis, intracranial hemorrhage, convulsion, septicemia, but cerebral palsy, neuro-developmental disorders, pulmonary, visual and hearing disorders cause severe 
disability. ${ }^{2,3}$ Diagnosis of patients in preterm labour is a challenge as more than $60 \%$ of patients with false diagnosis ,deliver at term without any treatment. ${ }^{4}$

Prediction of preterm labour has dominated research efforts for the past two decades or more. Regular cervical length assessment both clinically and by ultrasonography, use of biochemical markers such as placental corticotrophin releasing hormone $(\mathrm{CRH})$ and its binding protein, salivary estriol, inflammatory cytokines and prostaglandins, fetal fibronectin, and cervical ferritin have all been evaluated in the hope of obtaining a reliable predictor with high sensitivity and high negative predictive value, in order to indigenously manage patients at increased risk of preterm delivery. However, no single scoring system has been found to be a reliable tool till date. Hence, there is a need for a reliable test to predict the onset of preterm labour, identify those at risk and intervene early to prevent the preterm onset of labour as well as to avoid unnecessary hospital admission and use of tocolytic therapy.

One such test is the detection of phosphorylated insulinlike growth factor binding protein -1 (phIGFBP-1) in cervical secretion. Fetal membranes begin to detach from the decidua parietalis prior to the onset of labour at term. phIGFBP-1 present in the decidua, leaks into the cervical secretions. Hence, theoretically the risk of preterm labour can be determined by detection of phIGFBP- 1 in cervical secretions prior to term.

The detection of phIGFBP-1 in the cervical secretions of women presenting with preterm labour has been shown to be associated with an increased risk of preterm delivery. A bedside test-kit for phIGFBP-1 has been developed and is commercially available under the trade name Actim Partus (MedixBiochemica, Finland) and is marketed in India by Bharat Serums and Vaccines. In the present study, we evaluated efficacy of positive phIGFBP-1 bedside test in women with premature contractions in prediction of pretem labour.

This study was conducted to assess the efficacy of a bedside test kit for phIGFBP-1 in cervical secretion in prediction of preterm delivery in symptomatic patients. Secondary criteria were to correlate positive results with successful intervention to prolong pregnancy and improve delivery outcome.

\section{METHODS}

A prospective study was carried out at a tertiary hospital over a period of 2 years after taking approval from Institutional Ethics Committee. Women between 28 to 37 weeks of gestation with intact fetal membranes, who presented with threatened preterm labour (uterine contractions and vaginal discharge) were included. Exclusion criteria included women with preterm premature rupture of membranes (PPROM), blood mixed cervical secretions which interferes with test results, inevitable preterm labour, iatrogenic preterm induction of labour due to severe PIH, IUGR, or nonreassuring fetal condition.

Thirty consecutive women fulfilling the inclusion criteria were explained the procedure of the study and informed consent was taken. Detailed history including previous menstrual cycles, last menstrual period, obstetric history, medical and surgical illness, if any were noted. Abdominal examination was done for weeks of gestation, presentation of fetus and frequency of uterine contractions. Absence of local infection and amniotic fluid leak was confirmed on per speculum examination and the test for detection of phIGFBP1 was performed with Actim Partus kit.

Actim Partus is a commercially available one step immuno-enzymatic dipstick test for the detection of presence of phIGFBP1 in cervical secretion by monoclonal antibody 6303 as the detecting antibody specific for the ph IGFBP-1 with threshold of $10 \mu \mathrm{g} / \mathrm{L}$.

The kit contains sterile Dacron swab, test tube with 0.5 $\mathrm{ml}$ of extraction buffer solution and test dipstick. Specimen of cervical secretion was collected by insertion of sterile Dacron swab in the cervical canal just beyond the external os for 10 to 15 seconds. Once the cervical secretions were absorbed on the Dacron swab, it was dipped into the extraction buffer solution and swirled vigorously for 10 seconds.

The test dipstick was then dipped in the solution and the liquid front was seen over the indicator part of the dipstick. The dipstick was removed from the solution and kept horizontally for 5 minutes and the test result read at the end of 5 minutes. The test was positive if two blue lines appeared (control and result) and negative if only one blue line was seen, similar to other dipstick tests like urine pregnancy test. A strong positive result corresponds with sample extract that contains $30 \mu \mathrm{g} / \mathrm{L}$ or more of phIGFBP-1. A weak positive result corresponds to a level of $10-30 \mu \mathrm{g} / \mathrm{L}$ of phosphorylated IGFBP-1 in the cervical secretions as per manufacturers monogram. ${ }^{5}$

All the patients were admitted and complete blood count, routine examination of urine, high vaginal swab culture and sensitivity were done to determine etiological causes of preterm labour. Management was individualized, as tocolytics and steroids were given to patients with less than 34 weeks of gestation.

All recruited patients were followed up till delivery. Time interval between test and delivery, weeks of gestation at the time of delivery, labour and delivery details, mode of delivery and neonatal outcome i.e. birth weight, need for NICU care, perinatal morbidity and mortality were documented. Diagnostic accuracy of the test was determined by sensitivity, specificity, positive and negative predictive value. 


\section{Statistical analysis}

The data was analysed statistically using SPSS and Microsoft excel 2007. Enrolled women were analysed in two groups, less and more than 34 weeks of gestation as well as test to delivery interval was analysed for its significance in both positive and negative ph IGFBP -1 test results, using Chi square test. $\mathrm{P}$ value of $<0.05$ has been considered significant.

\section{RESULTS}

A total of thirty women were recruited for the study. The average age of enrolled women was 25 years (range19 to 35 years) and BMI was within normal limits.

Fourteen women $(46.66 \%)$ tested positive for pIGFBP -1 while sixteen women $(53.33 \%)$ tested negative. The mean gestational age was similar in both the groups (32 vs 32.5 weeks). Thirteen women in present study were primigravida and seventeen were multigravida. Risk factors for preterm delivery in all these women were studied.
Table 1: Risk factors for preterm delivery.

\begin{tabular}{|llll|}
\hline Risk factor & $\mathrm{n}(\%)$ & $\begin{array}{l}\text { Delivered } \\
\text { preterm }\end{array}$ & $\mathrm{n} \%$ \\
\hline Vaginal infection & $10(33.3)$ & 4 & 40 \\
\hline $\begin{array}{l}\text { Asymptomatic } \\
\text { bacteriuria (UTI) }\end{array}$ & $6(20)$ & 2 & 33.3 \\
$\begin{array}{l}\text { Previous preterm } \\
\text { delivery }\end{array}$ & $4(13.3)$ & 2 & 50 \\
\hline Multiple pregnancy & $2(6.7)$ & 1 & 50 \\
\hline $\begin{array}{l}\text { Acute medical } \\
\text { problems (fever) }\end{array}$ & $2(6.7)$ & 1 & 50 \\
\hline $\begin{array}{l}\text { Anemia } \\
\text { Polyhydromnios }\end{array}$ & $2(13.3)$ & 2 & 50 \\
\hline $\begin{array}{l}\text { Actim Partus } \\
\text { positive result }\end{array}$ & $14(46.7)$ & 1 & 50 \\
\hline
\end{tabular}

Risk factors were present in 25 women (15 of them had more than one risk factor). Vaginal infection $(n=10)$, asymptomatic bacteriuria $(n=6)$ were most common alongwith positive Actim Partus test results $(n=14)$ (Table 1). Preterm delivery was most frequent in women with positive Actim Partus results.

Table 2: Correlation of test results with preterm delivery.

\begin{tabular}{|llllll|}
\hline Test results & Gestational age at delivery & \multicolumn{2}{l|}{ Test to delivery interval } \\
& Less than 34 weeks & More than 34 weeks & Less than 48 hours & 48 hours to 7 days & More than 7 days \\
\hline Positive & $10(71 \%)$ & $4(29 \%)$ & $11(78.6 \%)$ & 2 & 1 \\
Negative & $4(25 \%)$ & $12(75 \%)$ & 2 & 3 & $10(66.6 \%)$ \\
\hline P value & 0.011 (significant) & & 0.001 (significant) & & \\
\hline
\end{tabular}

Table 2 shows correlation of p IGFBP 1 test results and gestational age at delivery as well as test to delivery interval. Fourteen women tested positive for ph IGFBP 1; of these 10 delivered before 34 weeks and four between 34 to 36 weeks. Sixteen women tested negative wherein four delivered before 34 weeks and twelve delivered between 34 to 37 weeks $(\mathrm{P}$ value $=0.011)$. The interval between conducting the test to delivery was less than 48 hours in eleven women who tested positive versus two who tested negative; was less than 7 days in 2 vs 3 and more than 7 days in 1 vs 10 women respectively ( $\mathrm{P}$ value $=0.001$ ) (Table 2). One patient with negative result absconded so could not obtain the delivery details.

The test was extremely sensitive in predicting preterm labour. $78.6 \%$ of patients with a positive test delivered within 48 hours, and all patients delivered within 14 days (prior to 36 weeks). The test was equally if not more useful when the result was negative as it was highly specific. $66 \%$ of patients with a negative test did not deliver preterm up to 7 days and $75 \%$ of them delivered after 34 weeks. Thus, a negative test result implies a low chance of preterm delivery. Sensitivity, specificity, positive and negative predictive value were as shown in the Table 3 .

Table 3: Efficacy of the test.

\begin{tabular}{|llll|}
\hline & \multicolumn{3}{c}{ Test to delivery interval } \\
\hline & $\mathbf{4 8}$ hour & $\mathbf{7}$ days & $\mathbf{1 4}$ days \\
\hline Sensitivity & $73.3 \%$ & $68.4 \%$ & $66.7 \%$ \\
\hline Specificity & $64.3 \%$ & $90 \%$ & $100 \%$ \\
\hline Positive predictive value & $68.8 \%$ & $92.9 \%$ & $100 \%$ \\
\hline Negative predictive value & $69.2 \%$ & $60 \%$ & $53.3 \%$ \\
\hline
\end{tabular}

In the patients with positive Actim Partus test result, the average time of prolongation of pregnancy was less than 24 hours and in patients with negative test result it was more than 7 days. The average birth weight was $1.5-2 \mathrm{~kg}$ in positive and $2.5-3 \mathrm{~kg}$ in negative result group. The need for NICU and perinatal morbidity was significantly less in patients with negative test result. Common causes of neonatal morbidity were acute respiratory distress syndrome followed by hypothermia and septicemia. Twelve babies transferred to NICU were from positive test group; of these 4 had hypothermia and 2 each for acute respiratory distress syndrome and necrotizing 
enterocolitis, 3 had septicemia and 1 intracranial hemorrhage. In the negative test group, only 3 had acute respiratory distress and 1 had septicemia. These results are summarized in Table 4.

Table 4: Correlation of test and pregnancy outcome.

\begin{tabular}{|llllllll|}
\begin{tabular}{|l} 
Test \\
result
\end{tabular} & Total no & $\begin{array}{l}\text { High } \\
\text { risk } \\
\text { factor }\end{array}$ & $\begin{array}{l}\text { Average time of } \\
\text { prolongation of } \\
\text { pregnancy }\end{array}$ & $\begin{array}{l}\text { Average } \\
\text { birth } \\
\text { weight }\end{array}$ & $\begin{array}{l}\text { A verage } \\
\text { Gestational }\end{array}$ & $\begin{array}{l}\text { Need } \\
\text { Ager at delivery }\end{array}$ & $\begin{array}{l}\text { Overall } \\
\text { NICU }\end{array}$ \\
Positive & 14 & 11 & Less than 24 hours & $1.5-2 \mathrm{~kg}$ & $32-34$ weeks & 13 & 12 \\
\hline Negative & $16($ labsconded) & 7 & More than 14 days & $2.5-3 \mathrm{~kg}$ & $34-36$ weeks & 5 & 4 \\
\hline
\end{tabular}

\section{DISCUSSION}

An accurate diagnosis of preterm labour is clinically difficult. Only about $20 \%$ of women presenting with signs and symptoms of preterm labour would actually deliver preterm. Various tools have been devised for the identification of women at risk of preterm delivery to decrease the unnecessary interventions for patients with symptoms of preterm labour and to identify patients who might benefit from aggressive therapy including tocolysis, corticosteroids, and intra-uterine transfer to a tertiary care facility.

Naoko Kozuki et al reported that early and late maternal age is an important risk factor for preterm labour. ${ }^{6}$ In present study $10 \%(n=3)$ were less than 20 years, $10 \%$ $(n=3)$ were more than 30 years age and none more than 35 years. Given a baseline risk of $10-12 \%$, the risk of recurrent preterm birth after 1,2 , and 3 consecutive preterm births may be increased to approximately $15 \%$, $30 \%$, and $45 \%$, respectively. ${ }^{7}$

In present study $13 \%$ patients had history of preterm deliveries and $50 \%$ them delivered before term. Most studies recommend considering a urine culture with more than $10^{5} \mathrm{CFU} / \mathrm{mL}$ as indicative of the presence of urinary tract infection in preterm labour women. ${ }^{8}$ Maternal GrB Strepticocci bacteriuria is considered a marker for genital tract colonization which poses a significant risk of preterm rupture of the membranes, premature delivery and early-onset severe neonatal infection however some studies failed to prove the association. ${ }^{9,10}$

In present study urinary tract infection was a common risk factor present in $20 \%$ of patients with preterm labour. Nair reported statistically significant increased risk of preterm delivery among anemic women, $27.9 \%$ preterm birth in anemic group and $7.2 \%$ in non-anemic group. ${ }^{11}$ Hussein Kidanto reported an incidence of preterm labour of $18 \%$ in anemic patients as compared to $12 \%$ in nonanemic control. ${ }^{12}$ In present study, anemia was present in $13.3 \%(n=4)$ of patients of which $50 \%$ delivered preterm.

There have been numerous studies on the use of insulin like growth factor binding protein IGFBP in the last ten years in India and other countries. Present study results correlate well with many of them. In present study, the sensitivity, specificity, positive value and negative predictive values of the test for estimation for delivery within 1 week of test were $68.4 \%, 90 \%, 92.9 \%, 60 \%$, respectively. The test was found to be more specific than sensitive in prediction of preterm labour.

Table 5: Comparison of various studies of Actim partus results for prediction of imminent delivery with 7 days.

\begin{tabular}{|c|c|c|c|c|c|}
\hline Reference study & Year & $\begin{array}{l}\text { Sensitivity } \\
(\%)\end{array}$ & $\begin{array}{l}\text { Specificity } \\
(\%)\end{array}$ & $\begin{array}{l}\text { Positive predictive } \\
\text { value }(\%)\end{array}$ & $\begin{array}{l}\text { Negative predictive value } \\
(\%)\end{array}$ \\
\hline Ting $^{13}$ & 2007 & 69 & 78 & 39 & 92 \\
\hline Tanir $^{14}$ & 2009 & 93.3 & 79.2 & 56 & 97.6 \\
\hline Brik spinelli $^{15}$ & 2010 & 73.1 & 66.2 & 21.8 & 95 \\
\hline Askar $\mathrm{AE}^{16}$ & 2012 & 74.3 & 61 & 76.3 & 73.6 \\
\hline Shikha singh $^{17}$ & 2013 & 72.2 & 90.6 & 81.3 & 85.3 \\
\hline Present study & 2009 & 68.4 & 90 & 92.9 & 60 \\
\hline
\end{tabular}

Two comparative studies show equivalent efficacy of ph IGFBP 1 versus fetal fibronectin and cervical length. The study by Riboni $\mathrm{F}$ was conducted in 2011 for prediction of preterm delivery among women with threatened preterm labour using fetal fibronectin and phosphorylated IGFBP- 1 in cervical secretion. ${ }^{18}$ 
Study included 210 patients between 24-34 weeks of gestation and prevalence of preterm delivery within one week was analysed. They concluded that phosphorylated IGFBP-1 test may be better than the fetal fibronectin test in predicting preterm delivery before 34 weeks of gestation as the logistic regression of ph IGFBP-1 was statistically significant in predicting preterm delivery with odds ratio of 10.08 .

Rolnik DL in 2013 conducted a study to investigate usefulness of measurement of cervical length and ph IGFBP-1 sequentially in prediction of preterm delivery. ${ }^{19}$ They concluded that both the tests were able to predict preterm delivery and sequential combination of both tests showed a high sensitivity and high negative predictive value. Present study shows that cervical detection of phosphorylated IGFBP-1 by immunochromotography is a rapid and easily applicable test that highly anticipates preterm delivery in patients at risk. Present study results also correlate favorably with published studies in the literature.

\section{CONCLUSION}

The limitation of the present study was that the sample size was small. However, our results show that there is a role for cervical IGFBP-1 test in the management of women presenting with suspected preterm labour; it may replace cervical ultrasonography and fetal fibronectin in the future or at least serve as a useful adjunct to these tests.

Thus, it will allow more focused management of women who are more likely to deliver preterm and perhaps avoid unnecessary admissions and treatment, to contain health care costs.

Funding: Bharat Serums and Vaccines Ltd

Conflict of interest: None declared

Ethical approval: The study was approved by the Institutional Ethics Committee

\section{REFERENCES}

1. Stacy B, Daniel W, Lale S, Ana Pilar B, Mario M, Jennifer HR, et al. The worldwide incidence of preterm birth: a systematic review of maternal mortality and morbidity. Bull World Health Organ. 2010;88:31-8.

2. McGowan JE, Alderdice FA, Holmes VA, Johnston L. Early childhood development of late-preterm infants: A systematic review. Pediatrics. 2011;127:1111-24.

3. Woythaler MA, McCormick MC, Smith VC. Late preterm infants have worse 24-month neurodevelopmental outcomes than term infants. Pediatrics. 2011;127:e622-e629.

4. Goldenberg RL, Culhane JF, Iams JD, Romero R. Epidemiology and causes of preterm birth. Lancet. 2008;371(9606):75-84.
5. Stock SJ, Morris RK, Chandiramani M, Shennan AH, Norman JE. Variation in management of women with threatened preterm labour. Archives of Disease in Childhood-Fetal and Neonatal Edition. 2014 Dec 19:fetalneonatal-2014.

6. Kozuki N, Lee AC, Silveira MF, Sania A, Vogel JP, Adair L et al. The associations of parity and maternal age with small-for gestational-age, preterm, and neonatal and infant mortality: a meta-analysis. BMC Public Health. 2013;13 Suppl 3:S2.

7. McMillan JA, Feigin RD, DeAngelis C, Jones MD, editors. Oski's pediatrics: principles and practice. Lippincott Williams and Wilkins; 2006.

8. Jain V, Das V, Agarwal A, Pandey A. Asymptomatic bacteriuria and obstetric outcome following treatment in early versus late pregnancy in north Indian women. Indian J Med Res. 2013;137:753-8.

9. Verani JR, McGee L, Schrag SJ. Prevention of perinatal group B streptococcal disease revised guidelines from CDC, 2010. MMWR. 2010;59:1-31.

10. Chen YK, Chen SF, Li HC, Lin HC. No increased risk of adverse pregnancy outcomes in women with urinary tract infections: a nationwide populationbased study. Acta Obstet Gynecol Scand. 2010;89:882-8.

11. Nair A, Chandana C, Venkatesh S, Kumar S. Evaluation of maternal anemia in tertiary care centre and its neonatal outcomes. nt J Reprod Contracept Obstet Gynecol. 2016;5(10):3506-11.

12. Kidanto HL, Mogren I, Lindmark G, Massawe S, Nystrom L. Risk for preterm delivery and low birth weight are independently increased in severity of anemia. S Afr Med J. feb 2009;99:98-102.

13. Ting HS, Chin PS, Yeo GSH, Kwek K. Comparison of BedsideTest Kits for Prediction of Preterm Delivery: Phosphorylated Insulin-like Growth Factor Binding Protein-1 (pIGFBP-1) Test andFetal Fibronectin Test. Ann Acad Med Singapore. 2007;36:399-402.

14. Tanir HM, Sener T, Yildiz Z. Cervical phosphorylated insulin-like growth factor binding protein-1 for the prediction of preterm delivery in symptomatic cases with intact membranes. J Obstet Gynaecol Res. 2009;35:66-72.

15. Brik Spinelli M, Hernández AIM, Pedraz CC, Perales A. Phosphorylated insulin-like growth factor binding protein-1 and cervical measurement in women with threatening preterm birth. Acta Obstet Gynecol Scand. 2010;89:268-74.

16. El-Ezz AE, Askar AE. Predictive value of phosphorylated insulin-like growth factor binding protein-1 (PIGFBP-1) (bedside test) in preterm labor. J Egypt Soc Parasitol. 2014;44(2):525-30.

17. Singh S, Singh S, Chandra M, Rani R, Verma S. A study to evaluate the efficacy of Actim Partus (A Rapid Bedside Test) in prediction of preterm labour. Indian J Clin Pract. 2013;24:260-3.

18. Riboni F, Vitulo A, Dell'avanzo M, Plebani M, Battagliarin G, Paternoster D. Biochemical markers predicting pre-term delivery in symptomatic patients: 
phosphorylated insulin-like growth factor binding protein-1 and fetal fibronectin. Arch Gynecol Obstet. 2011;284(6):1325-9.

19. Rolnik DL, Bittar RE, Carvalho MH, Zugaib M, Francisco RP. Preterm birth prediction: sequential evaluation of the cervix and the test for phosphorylated protein-1 linked to insulin-like growth factor. Erog Rev Bras Ginecol Obstet. 2013;35(9):394-400.

Cite this article as: Vishwekar PS, Chauhan AR, Turakhia N. Prediction of preterm delivery with a novel bedside test. Int J Reprod Contracept Obstet Gynecol 2017;6:3366-71. 